\title{
NREL Publishes Deployment-Focused "Composite Data Products" for Fuel Cell Demonstrations Funded by the American Recovery and Reinvestment Act (ARRA)
}

NREL Team: Jennifer Kurtz, Keith Wipke, Sam Sprik, and Todd Ramsden

Accomplishment: NREL recently published the first set of results for the ARRA-funded early fuel cell markets project (first reported in April 2010). These results specify the speed and scale of the deployment along with the applications for the systems.

Context: The U.S. Department of Energy (DOE) has designated more than $\$ 40$ million in ARRA funding for the rapid deployment of approximately 1,000 fuel cell systems across the United States. These deployments will facilitate the development of fuel cell technology, manufacturing, and operation in strategic markets-material-handling equipment, backup power, and stationary power-where fuel cells can compete with conventional technologies.

A key component of this project involves data collection, analysis, and reporting. NREL's Hydrogen Secure Data Center serves as the central location for data analysis. The data are reported in the form of "composite data products" (CDPs), which mask proprietary data by aggregating findings from multiple projects.

DOE announced the awards in April 2009, and deployment is quickly progressing. While awaiting the first round of operational data, NREL created a group of CDPs highlighting the speed and scale of the deployments. The following figure shows the number of fuel cell units in operation (or estimated to be in operation) by quarter and their applications.

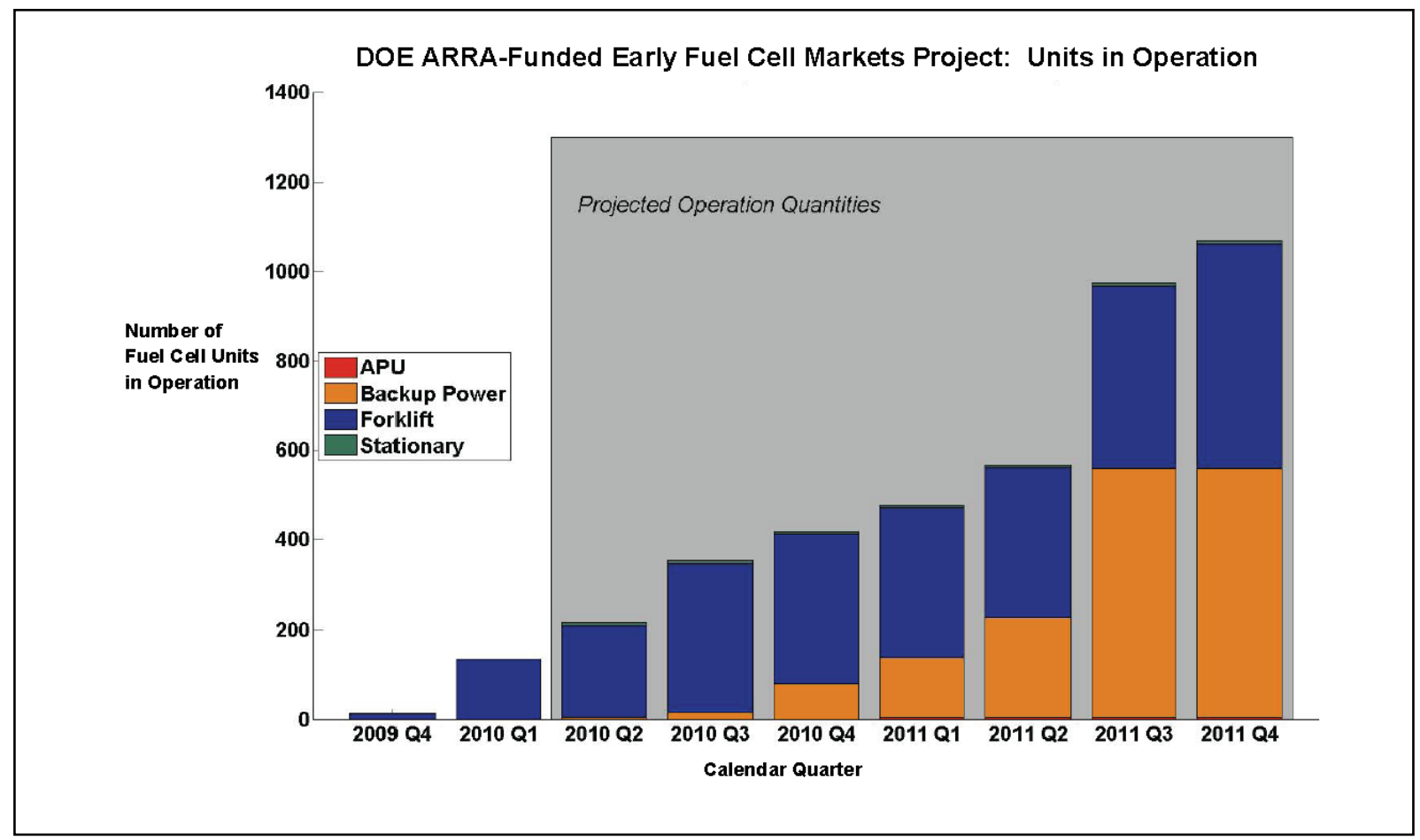

Applicable DOE Technical Target: Accelerate the commercialization of fuel cells through the deployment of approximately 1,000 ARRA-funded fuel cell units.

Significance of Accomplishment: NREL's first round of CDPs highlights the speed, scale, and diversity of ARRA-funded fuel cell projects. These deployment-focused CDPs indicate the significant amount of real-world operational data that NREL will collect and study. NREL expects to release its first round of technical analysis results later in 2010. All reports and CDPs are available at www.nrel.gov/hydrogen/proj fc market demo.html. 